Hydrology and Earth System Sciences, 8(3), 449-459 (2004) C EGU

\title{
The influence of riparian woodland on the spatial and temporal variability of stream water temperatures in an upland salmon stream
}

\author{
Iain A. Malcolm¹, David M. Hannah², Mike J. Donaghy ${ }^{3}$, Chris Soulsby ${ }^{1}$ and Alan F. Youngson ${ }^{3}$ \\ ${ }^{1}$ Department of Geography and Environment, University of Aberdeen, Elphinstone Road, Aberdeen AB24 3UF, UK \\ ${ }^{2}$ School of Geography, Earth and Environmental Sciences, University of Birmingham, Edgbaston, Birmingham B15 2TT, UK \\ ${ }^{3}$ Fisheries Research Services (FRS) Freshwater Laboratory,Faskally, Pitlochry, Perthshire PH16 5LB, UK
}

Email for corresponding author: i.a.malcolm@marlab.ac.uk

\begin{abstract}

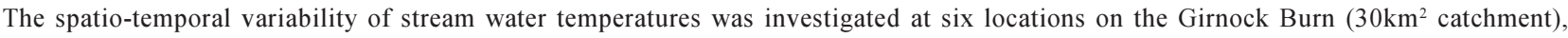
Cairngorms, Scotland over three hydrological years between 1998 and 2002. The key site-specific factors affecting the hydrology and climatology of the sampling points were investigated as a basis for physical process inference. Particular emphasis was placed on assessing the effects of riparian forest in the lower catchment versus the heather moorland riparian zones that are spatially dominant in the upper catchment. The findings were related to river heat budget studies that provided process detail. Gross changes in stream temperature were affected by the annual cycle of incoming solar radiation and seasonal changes in hydrological and climatological conditions. Inter-annual variation in these controlling variables resulted in inter-annual variability in thermal regime. However, more subtle inter-site differences reflected the impact of site-specific characteristics on various components of the river energy budget. Inter-site variability was most apparent at shorter time scales, during the summer months and for higher stream temperatures. Riparian woodland in the lower catchment had a substantial impact on thermal regime, reducing diel variability (over a period of 24 hours) and temperature extremes. Observed inter-site differences are likely to have a substantial effect on freshwater ecology in general and salmonid fish in particular.
\end{abstract}

Keywords: temperature, thermal regime, forest, salmon, hydrology, Girnock Burn, Cairngorm

\section{Introduction}

Stream temperature is a key aspect of water quality affecting physical, chemical and biological processes (e.g. Arscott et al., 2001; Malard et al., 2001; Poole and Berman, 2001; Gu and $\mathrm{Li}, 2002)$. It is a particularly important variable for poikilothermic species (Langan et al., 2001) including invertebrates (Boon, 1987, 1993; Hawkins et al., 1997) and fish (Crisp, 1996). Temperature affects invertebrate community structure (Townsend et al., 1983) and, hence, the metabolism, growth and development of salmonids (Elliot and Hurley, 1998; Jones et al., 2002) and other freshwater fish species. Consequently, a knowledge of the factors determining spatial and temporal variability of stream water temperature is essential to understanding many aspects of freshwater ecology. Numerous accounts of temperature variation are available, often based on data from large catchments integrated over prolonged periods. However, many potentially susceptible biological processes vary on much shorter time scales. Despite this, relatively few studies have examined the spatial and temporal variability of stream water temperature at fine spatial scales in small headwater catchments. In the UK, such headwater catchments are often characterised by some degree of riparian tree cover (Brogan and Soulsby, 1996). This may be plantation forest, or seminatural woodland, both of which can have a profound effect on stream temperature.

Air temperature, often used to predict stream water temperature (Webb and Nobilis, 1997), is only a good 
predictor at moderate air temperatures $\left(0-20^{\circ} \mathrm{C}\right.$; Mohehsi and Stefan, 1999). For upland and high latitude rivers, where sub-zero air temperatures can occur over prolonged periods, air temperature is likely to be a poor predictor of stream temperature. In such environments, empirical, spatially and temporally-distributed observations of stream temperatures are necessary to characterise the thermal regime of streams.

Theoretical understanding of the thermal processes operating in streams is well-established. Stream temperatures are controlled by energy (heat) inputs to and losses from the watercourse ( $\mathrm{Gu}$ and $\mathrm{Li}, 2002)$. Nonadvective inputs include: incident short-wave (solar) and long-wave radiation (downward atmospheric), condensation, friction at the bed and banks, and heat released by chemical and biological processes. Non-advective outputs include: reflection of short-wave radiation, emission of long-wave (back) radiation and evaporation (Webb and Zhang, 1997; Evans et al., 1998; Hannah et al., in press). Sensible heat fluxes and energy transfers between the channel and its bed can add or remove heat. Advective heat exchanges (i.e. horizontal transport) can be positive or negative and may include; tributary inflow, evaporated water, groundwater-surface water interactions, and precipitation (Webb and Zhang, 1997; Evans et al., 1998; Hannah et al., in press). Riparian forestry can have a major effect on various components of the stream energy budget, affecting both energy inputs and outputs (Sinokrot and Stefan, 1993). Consequently, riparian tree cover has the potential to affect the functioning of aquatic ecosystems (Weatherley and Ormerod, 1990).

The relative importance of energy inputs and losses varies over space and time depending on site-specific characteristics, as well as on hydrological and meteorological conditions (Webb and Zhang, 1997; Poole and Berman, 2001). A summary of the main spatial and temporal controls upon individual components of the river energy budget is provided by Webb and Zhang (1997). Briefly, the main factors affecting the spatial variability of energy exchange in addition to riparian vegetation are: aspect, channel geomorphology, valley topography, substrate characteristics and the location of tributary and groundwater inflows. Factors affecting the temporal variability of energy exchanges include: the annual cycle of incoming solar radiation, and seasonal changes in hydrological conditions, wind speed, humidity, air and water temperatures, and vegetation growth.

The Girnock Burn (an upland, sub-arctic stream in the Cairngorm mountains, north-east Scotland) is a research site where Atlantic salmon (Salmo salar) populations and environmental conditions have been monitored for over 40 years. The stream drains a moorland catchment, though the lower $2 \mathrm{~km}$ have extensive riparian tree cover, dominated by Scots pine (Pinus sylvestris), alder (Alnus glutinosa) and birch (Betula pendula). Previous studies of stream temperature in the Girnock Burn have investigated the longterm (30 year) temporal variability of stream water temperatures at a single site in the forested lower catchment (Langan et al., 2001) and the temporal variability of energy fluxes, at a moorland site in the upper catchment over a 24 week period (Hannah et al., in press). Stream temperatures have also been used to model growth in juvenile salmon within a single reach of the catchment (Jones et al., 2002). Net growth was shown to be a trade-off between food assimilation and basal maintenance, both of which were affected by temperature. Maximum growth occurred in early spring (year days 100-200) when stream temperatures permitted rapid assimilation of food but were not so high that basal maintenance levels cancelled out gains (as occurred during the summer months). This model was parameterised using average daily temperature. However, exploratory analysis of stream temperature records suggests that daily temperature variation, in early summer, covers a large part of the seasonal and even annual temperature range. Further consideration of the spatial and temporal variability of stream temperature is required to accommodate fine-scale change and to assess differences in growth performance at other sites in the catchment.

This paper investigates the variability of stream water temperatures at six sites distributed throughout the Girnock Burn stream network over three hydrological years (October-September) between 1998 and 2002. The aims are (1) to characterise the spatial and temporal dynamics of stream water temperatures within the catchment over the three-year period; (2) to identify the key hydrological, climatological and site-specific factors affecting stream temperature and, thereby, infer the physical processes driving thermal variability; and (3) to assess the implications of spatial and temporal water temperature variations for stream ecology.

\section{FIELD SITE}

Glen Girnock is a semi-natural upland catchment draining part of the Lochnagar massif into the Aberdeenshire Dee (Fig. 1). The catchment ranges in altitude from approximately $230 \mathrm{~m}$ at the confluence with the Dee to $862 \mathrm{~m}$ at the summit of Caisteal na Caillich and drains an area of approximately $30.3 \mathrm{~km}^{2}$. The geology of the area is described in detail elsewhere (Malcolm, 2002). In summary, igneous rocks ranging from granite to diorite are present at higher altitudes in the catchment, while the valley floors and sides are composed of metamorphosed Dalradian rocks, 


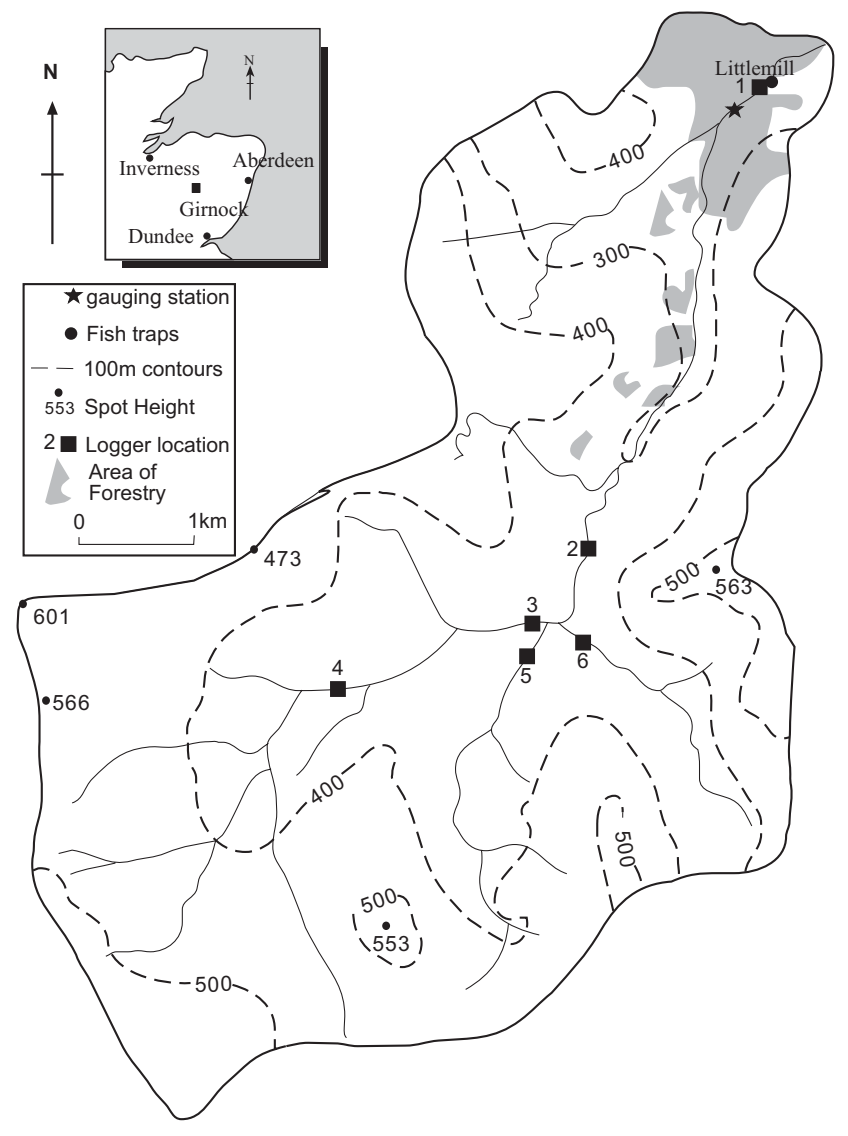

Fig. 1. Map showing the Girnock Burn catchment, the location of temperature loggers, fish traps, SEPA gauging station and major areas of forestry.

primarily schists, which are often calcareous. The solid geology is overlain by a variety of glacial, fluvioglacial and peri-glacial sedimentary deposits (Soulsby and Boon, 2001). Groundwater upwelling occurs at discrete locations in the upper catchment where till deposits result in valley constriction or where distinct geological boundaries exist (Hannah et al., in press; Youngson et al., in press). The lower catchment is underlain by a suite of coarse fluvio-glacial deposits in the Dee floodplain and is thought to be effluent in nature (Malcolm et al., 2002; Youngson et al., in press).

Peats, podzols and gleys comprise the dominant soil types, together with substantial areas of brown forest soils in the more steeply sloping areas of the lower catchment. Soils are derived from local granitic and igneous rock parent material in the south and west of the catchment, various glacial drift deposits in the north and east, and fluvioglacial sands and gravels in the extreme north, at the confluence with the Dee. Catchment land-use is dominated by heather (Calluna) moorland, though small areas of commercial forestry and semi-natural riparian woodland are found in the lower catchment (Moir, 1999).

The Girnock Burn receives approximately $1100 \mathrm{~mm}$ of precipitation annually, with up to $25 \%$ falling as snow (Warren, 1985). May-August are normally the driest months, with the majority of precipitation falling between November-January. Air temperatures in Glen Girnock are highly variable. For example, Moir (1999) reported maximum and minimum temperatures of $31^{\circ} \mathrm{C}$ and $-27^{\circ} \mathrm{C}$, respectively, during 1995, at Littlemill (Fig. 1) in the lower Girnock. A gauging station operated by the Scottish Environmental Protection Agency (SEPA), installed at Littlemill in 1969, provides 15-minute resolution discharge data. Mean daily flow varies markedly, from $0.01 \mathrm{~m}^{3} \mathrm{~s}^{-1}$ in summer (June-August) to an estimated $23 \mathrm{~m}^{3} \mathrm{~s}^{-1}$ during winter floods (Moir, 1999).

\section{METHODOLOGY}

Stream temperature was monitored at six locations along the Girnock Burn stream network. Four sites were located on the main channel, while the remaining two sites provided additional stream temperature data from tributary streams draining the upper catchment (Fig. 1). A summary of reach characteristics, including riparian vegetation, bedslope gradient, bankfull width/depth ratios, catchment area, altitude and azimuth is provided in Table 1.

Temperature was recorded using Gemini TinytagPlus micro-dataloggers with integrated thermistors to a reported

Table 1. Physical characteristics of temperature data logger study reaches.

\begin{tabular}{|c|c|c|c|c|c|c|c|}
\hline Site & $\begin{array}{l}\text { Riparian } \\
\text { Vegetation }\end{array}$ & $\begin{array}{l}\text { Bedslope } \\
(\%)\end{array}$ & $\begin{array}{l}\text { Width / Depth } \\
\text { Ratio }\end{array}$ & $\begin{array}{l}\text { Catchment } \\
\text { Area }\end{array}$ & Altitude & Reach & $\begin{array}{l}\text { Azimuth, degrees } \\
\text { from due South }\end{array}$ \\
\hline 1 & Mixed Forest & 0.21 & 8.86 & 28.7 & 240 & Pool - riffle & 0 \\
\hline 2 & Heather Moorland & 2.19 & 8.67 & 19.935 & 310 & Run & 0 \\
\hline 3 & Heather Moorland & 1.96 & 7.23 & 11.9 & 320 & Run & 48 \\
\hline 4 & Heather Moorland & 3.14 & 4.16 & 9.1 & 350 & Step - Pool & 78 \\
\hline 5 & Heather Moorland & 2.13 & 7.77 & 4.19 & 320 & Pool - riffle & 29 \\
\hline 6 & Heather Moorland & 2.14 & 4.15 & 3.25 & 320 & Pool - riffle & 58 \\
\hline
\end{tabular}


accuracy of $\pm 0.2^{\circ} \mathrm{C}$. The loggers were contained in perforated, protective housings attached to the stream bank to minimise damage to loggers during floods, especially those accompanied by significant river ice break-up. Data were logged at 30-minute resolution. Loggers were crosscalibrated over a range $0-25^{\circ} \mathrm{C}$ prior to installation and showed excellent agreement (within $0.1^{\circ} \mathrm{C}$ ). A second datalogger was periodically run alongside previously installed units to assess the continued accuracy of the readings. In addition, spot checks of stream temperature were made approximately monthly during data download using a mercury-in-glass thermometer read to $0.1^{\circ} \mathrm{C}$. These manual measurements were related back to logged values; there was no evidence of drift in the accuracy of the logging units over the period of study.

Due to the extreme conditions encountered in upland environments such as the Girnock Burn, there were occasions, primarily during high flow conditions, where data loggers malfunctioned, or were washed up onto the bank. The functioning and positioning of dataloggers was checked following major floods and, where necessary, spurious data (for example where displaced loggers had measured air temperature) was screened out from the record.

Hourly air temperature data were provided by the BADC (British Atmospheric Data Centre) for the nearby UK Met Office station at Aboyne (approximately $20 \mathrm{~km}$ east of Littlemill). Channel reach characteristics were surveyed using a Leica TC705 total station. Catchment and subcatchment areas and azimuth (degrees from due south,) were calculated from Sheet 44 of the Ordnance Survey Landranger series maps as detailed by Arscott et al. (2001).

\section{Results}

\section{HYDROLOGICAL AND CLIMATOLOGICAL} CONTEXT

The temperature and river flow time-series presented below provide a hydroclimatological context for the investigation of spatial and temporal variability in stream water temperatures.

Air temperatures for Aboyne exhibited the sinusoidal annual patterns expected for the Northern Hemisphere, broadly reflecting changes in incoming solar radiation (Fig. 2a). Maximum temperatures were recorded between JulyAugust $\left(20.5^{\circ} \mathrm{C}\right)$. Minimum temperatures were recorded between February-April $\left(-14.3^{\circ} \mathrm{C}\right)$. The hydrological year 2000-01 was characterised by both the highest and lowest temperatures (Fig. 2). The years 2001-02 and 1999-00 exhibited reduced temperature maxima and minima (Fig. 2).

The Girnock Burn exhibits a flashy hydrological regime,

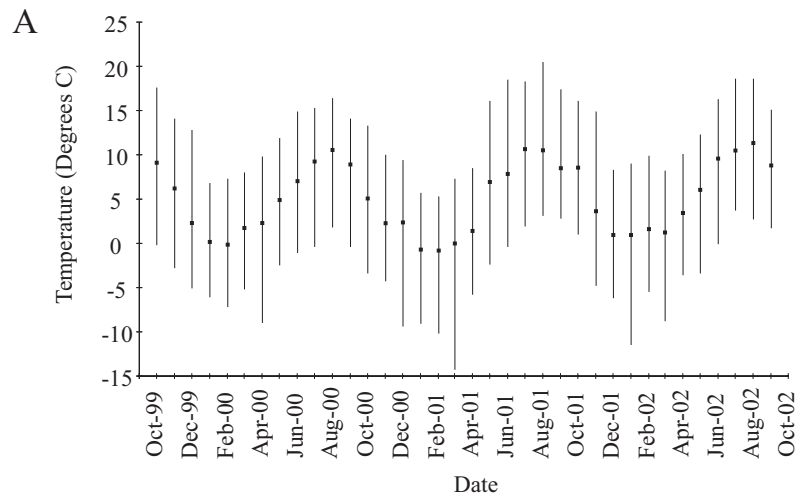

B

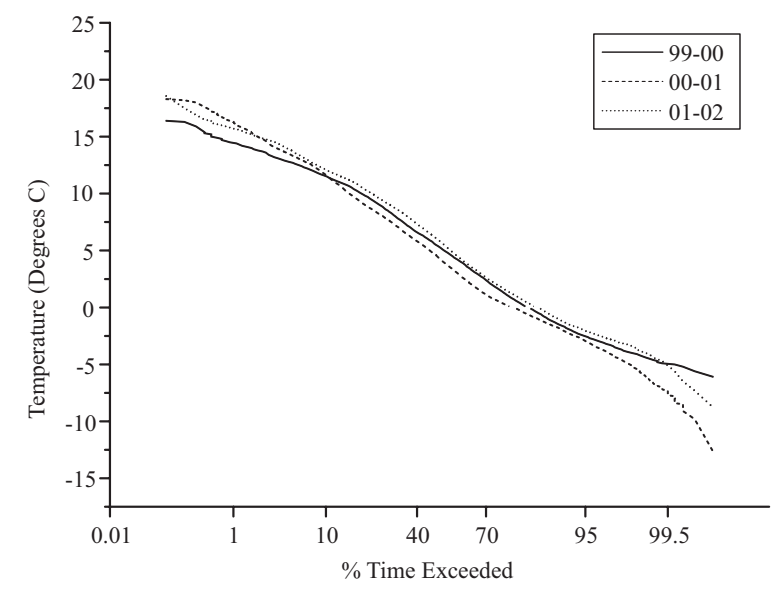

Fig. 2. Air temperature from Aboyne. Mean, maximum and minimum monthly air temperatures (A) and air temperature duration curves for the three hydrological years 1999-2002 (B).

indicated by the steepness of the flow duration curve (Fig. 3a). Streamflow can peak and return to near baseflow conditions within 24 hours. The period May-September is generally characterised by declining summer baseflows (Fig. $3 b)$. The period from October-April is generally characterised by higher winter baseflows punctuated by hydrological events of varying magnitude $\left(0.2-22 \mathrm{~m}^{3} \mathrm{~s}^{-1}\right)$. The 2001-02 hydrological year was the wettest studied, exhibiting the highest peak flow (estimated at approximately $38 \mathrm{~m}^{3} \mathrm{~s}^{-1}$ ) and the highest base flows (Fig. 3). The hydrological years 1999-00 and 2000-01 were similar in terms of annual streamflow characteristics, although 19992000 experienced marginally lower summer baseflows (Fig $3 b)$.

\section{SPATIAL VARIABILITY IN STREAM WATER} TEMPERATURES

\section{Annual}

Temperature duration plots for the three hydrological years 1999-02 revealed clear differences in thermal regime 
A

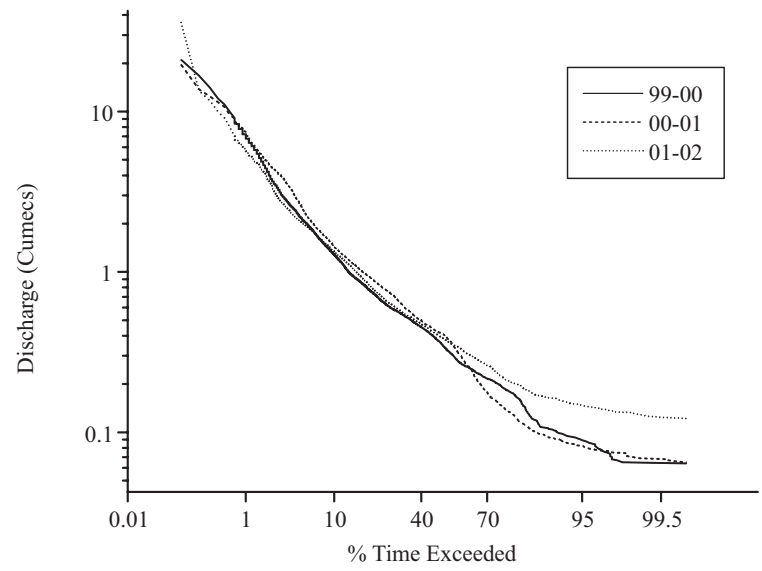

$\mathrm{B}$

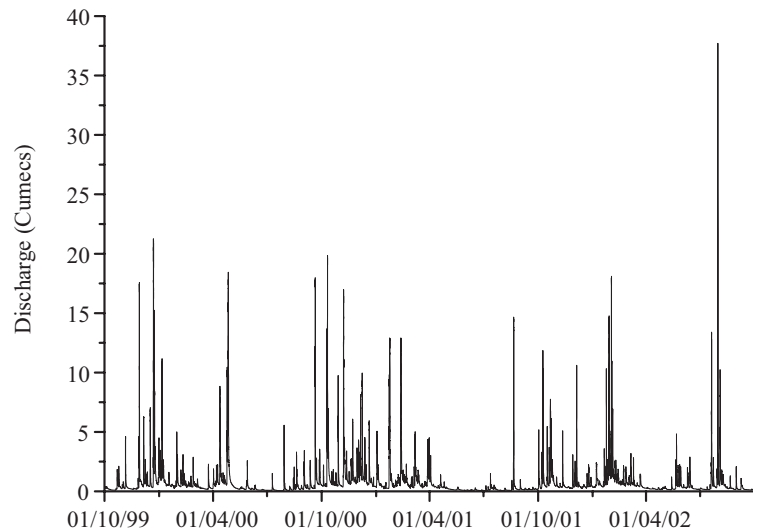

Fig. 3. Girnock discharge characteristics between 1999 and 2002. Flow duration curves (A) and three-year hydrograph (B), constructed from 15-minute resolution discharge data provided by SEPA for the Littlemill gauging station.

between sites (Fig. 4). For the hydrological year 1999-00, data were available only for the four-main-stem sites (Fig. 4a). Two clear pairings were evident: (1) Sites 2 and 3 (2) Sites 1 and 4 . The most marked inter-site differences were observed for higher stream temperatures $\left(>8^{\circ} \mathrm{C}\right)$. Site 1 (the lowest site) exhibited a similar thermal regime to Sites 2 and 3 below approximately $12^{\circ} \mathrm{C}$, while site 4 (the highest site) exhibited a similar thermal regime below approximately $7^{\circ} \mathrm{C}$. Above these temperatures, Sites 1 and 4 exhibited attenuation of temperature maxima. All sites experienced similar responses at low temperatures due to freezing water temperatures at times of river icing (Hannah et al., in press).

Stream temperature data were available for all six sites during 2000-01. Minimum and maximum air temperatures were more extreme during this year than 1999-00 (Fig. 2) and this was reflected in stream water temperatures (Fig 4b). Inter-site differences were once again apparent with the clearest differences being observed at higher stream temperatures. Sites were ordered $1>4>6>5>2>3$ according to the degree of attenuation observed at higher temperature.

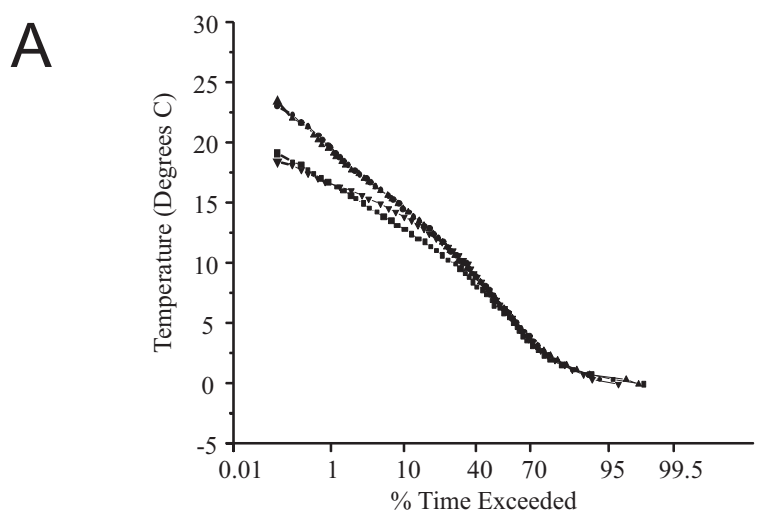

B

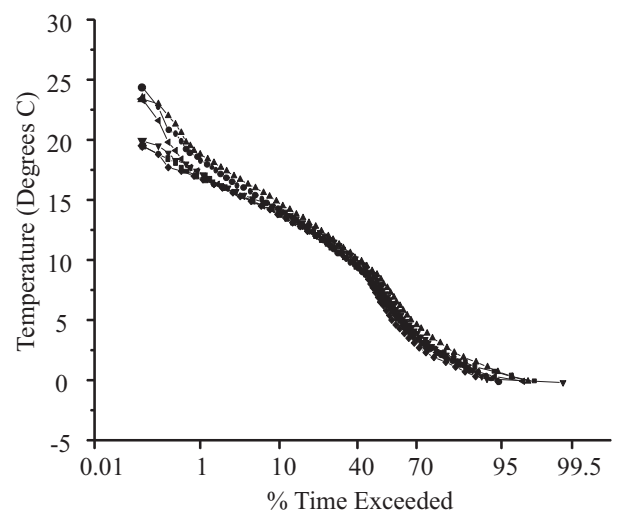

C

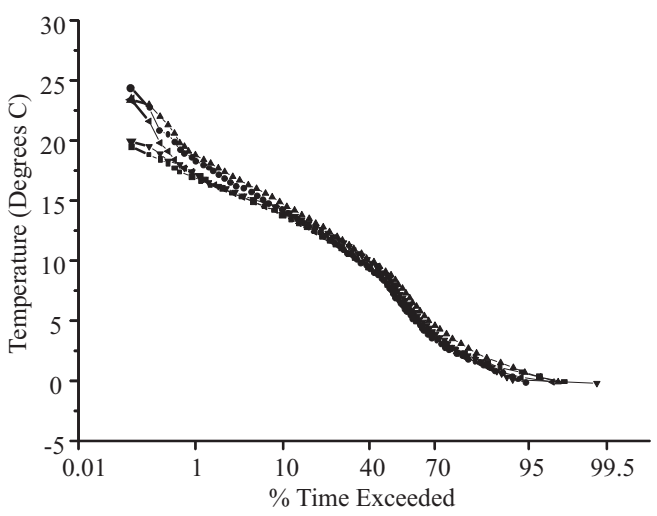

Fig. 4. Temperature duration curves for the hydrological years 1999-00 (A), 2001-01 (B) and 2001-02 (C) at sitesl( $\mathbf{\nabla ) , ~} 2$ ( $\mathbf{\Delta ) ,}$ $3(\bullet), 4(\mathbf{\square}), 5(\bullet), 6(\bullet)$.

Although temperature duration curves also appeared to vary for lower stream temperatures, all sites ultimately experienced freezing (sub-zero) water temperatures for prolonged periods of time (7-12\%). It is unknown whether loggers were actually encased in ice at this time. However, field observations were made of total icing of the stream surface during the winter of 2000-01.

Data were again available for all six sites during the 20012002 hydrological year. However, Site 5 was removed from the analysis due to prolonged periods where temperature 
readings were either unavailable or unreliable. Inter-site differences were again more apparent for high than low temperatures (Fig. 4c). For high temperatures, the sites were ordered $4>1>6>3>2$, according to the degree of attenuation.

Despite inter-annual variability in hydrological and meteorological conditions and the impact that this has on stream temperatures, some common features are consistent among years. In all three years, the main-stem Sites 1,4 and Sites 2,3 group together. Inter-site variability was more apparent for high than low stream temperatures. Most notably, Sites 1 (forested location) and 4 (uppermost monitoring location) exhibited thermal moderation at high stream temperatures when compared with other sites despite having markedly different site characteristics (Table 1). The two tributary sites exhibited temperature characteristics intermediate to the two main-stem groups. Inter-site differences were, as expected, most apparent in 2000-01 when air temperatures (maximum and minimum) were most extreme.

\section{Monthly}

Mean monthly stream water temperatures exhibited sinusoidal annual patterns (Fig. 5), broadly similar to that of air temperature. The coldest mean monthly temperatures were observed between December-February and highest temperatures between July-August. The clearest inter-site differences were associated with high stream temperatures (Fig. 5) and low stream flow (Fig. 3) between May-August of 2000 and 2001. During these periods, mean monthly temperatures showed generally consistent patterns of intersite variability. Sites 2 and 3 were the warmest sites and Site 4 was the coldest of the sites. Sites 5 and 6 exhibited intermediate characteristics. Site 1 was more variable, sometimes exhibiting characteristics similar to those of Sites 2 and 3 and, at other times, exhibiting marginally lower mean monthly temperatures. Inter-site differences between autumn and early spring were small and inconsistent.

Inter-site differences were most apparent for monthly maxima between May-October (Fig. 6), indicating the importance of individual site characteristics at higher stream temperatures. The highest monthly maxima were usually recorded at Sites 2 and 3. Lowest monthly maxima were usually recorded at Sites 1 and 4 . Sites 5 and 6 once again exhibited intermediate characteristics. Monthly maxima were similar between sites during the cooler months between November-April. There was little inter-site variability in monthly minima between November-March. However, as stream temperatures increased during the spring and summer, Site 1 exhibited some evidence of elevated minimum temperatures.

\section{Diel}

Seasonal variations in energy receipt were reflected in average temperature signals over a, diel, period of 24 hours.. Figure 7 shows mean diel temperature signals for four months, which represent the four calendar seasons. During the winter, the amplitude of the diel temperature signal was low and differences between sites were within the measurement error of the dataloggers (Fig. 7a).

The amplitude of the mean diel temperature signal increased in April in response to increasing day length (Fig. $7 b)$. Site 4 exhibited the lowest daily range $\left(3 \cdot 4^{\circ} \mathrm{C}\right)$. In addition, stream temperatures began to rise earlier in the morning than at other sites, and peaked earlier in the afternoon. At Site 2, daily maximum temperatures exceeded those elsewhere in the catchment. Stream temperatures rose

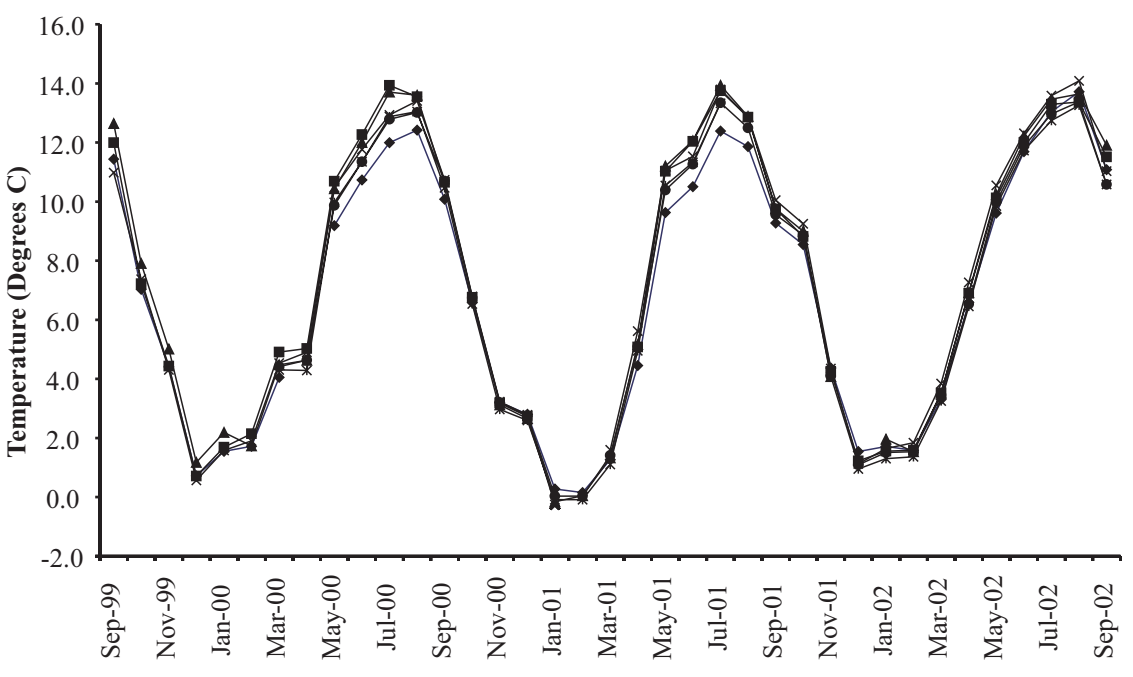

Fig. 5. Mean monthly temperatures in the Girnock Burn at sites $1(\mathbf{X}), 2(\boldsymbol{\nabla}), 3(\mathbf{\square}), 4(\bullet), 5(*), 6(\bullet)$. 


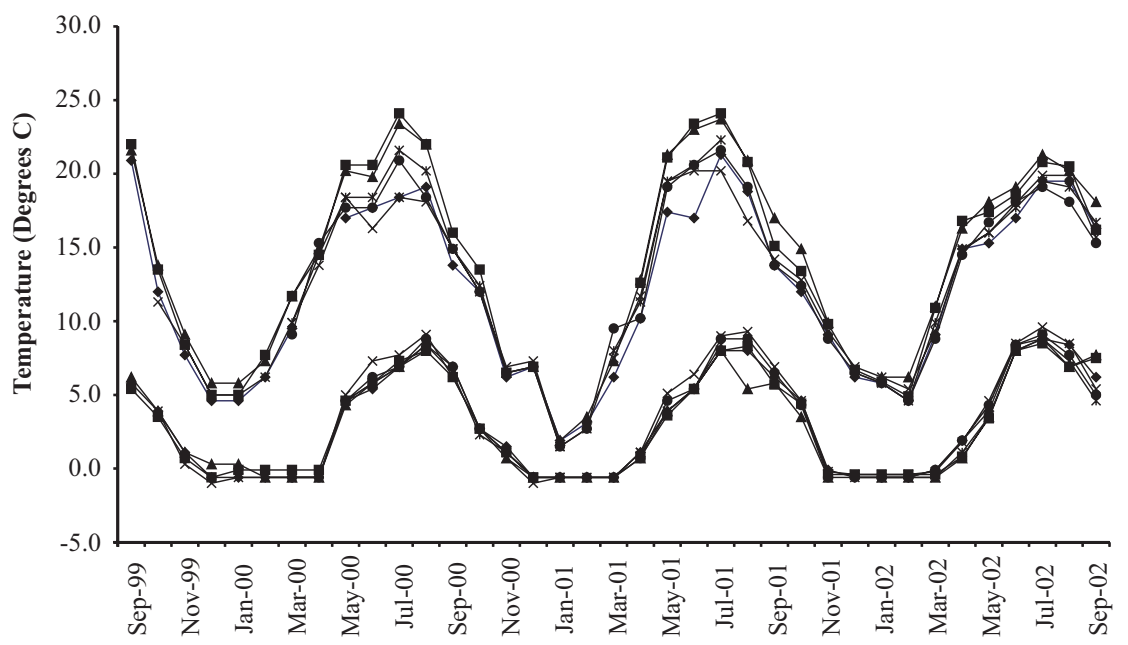

Fig. 6. Maximum and minimum monthly temperatures in the Girnock Burn at sites $1(\mathbf{X}), 2(\nabla), 3(\bullet), 4(\bullet), 5(*), 6(\bullet)$.

and declined sharply and peaked simultaneously with Site 1, approximately $0.5 \mathrm{~h}$ prior to Sites 3,5 and 6 . Site 1 exhibited the highest night-time temperatures of all the sites, but daytime temperatures peaked below those of Sites 2 and 3 , probably reflecting the influence of forestry versus more open locations. Sites 5 and 6 exhibited broadly similar temperature signals, although Site 5 exhibited slight moderation of temperature extremes and, thus, a reduced temperature range.

Stream temperatures increased into August. Data were not available from Site 6 during August due to datalogger failure (Fig. 7c). The amplitude of the diel temperature signal increased at all sites except Site 1 . Site 4 was again the coldest of the sites. Site 2 again exhibited the greatest diel range, but Site 3 warmed earlier in the day and reached its peak temperature first. The amplitude of the mean diel temperature signal at Sites 2 and 3 exceeded $5^{\circ} \mathrm{C}$. For individual days in August the amplitude of the diel temperature signal exceeded $10^{\circ} \mathrm{C}$. Site 1 exhibited the lowest diel temperature range of all the sites (Fig. 7c) and daily maxima lagged between 1.5 and 3 hours behind the other sites. Site 6 also exhibited substantial thermal dampening when compared with Sites 2 and 3, with higher minimum and lower maximum temperatures.

Stream temperatures declined in October in response to shortening day length (Fig. 7d). The amplitude of the diel temperature signal also declined at all sites. Site 4 remained the coldest of all sites exhibiting lowest minimum and maximum temperatures. Sites 2 and 3 peaked synchronously, although temperatures began to rise 0.5 hours earlier at Site 2 which exhibited the highest maximum temperature of all the sites. Sites 1 and 6 again exhibited high minimum temperatures. Site 1 exhibited the second highest maximum temperatures, behind Site 2 .

\section{Discussion}

In the absence of stream energy balance measurements for each location, the key site-specific factors affecting the hydrology and climatology of the sampling points along the Girnock Burn were investigated as a basis for physical process inference. The findings of detailed specific river heat budget studies (Webb and Zhang, 1997; Evans et al., 1998; Hannah et al., in press) are used to provide a theoretical context for discussion of results. The implications of the study are discussed with reference to ecological processes in general and salmonid ecology more particularly.

Gross changes in stream temperature in the Girnock Burn were affected by the annual cycle of incoming solar radiation, seasonal changes in hydrological conditions, windiness, humidity and air temperature. Inter-annual variation in these controlling variables resulted in interannual variability in the thermal regime of Girnock sites. However, more subtle inter-site differences reflected the impact of site-specific characteristics on various components of the energy budget. This paper has shown that the effect of these local, reach scale factors can be important to temperatures especially at shorter temporal scales. The effect of riparian tree cover appears to be critical in this regard as Site 1 often exhibited a distinct thermal regime.

Inter-site variability was most apparent during the summer months and for high, rather than low, stream temperatures. Net radiation dominates energy inputs during the summer months (Webb and Zhang, 1997; Evans g :et al., 1998). Consequently, inter-site differences probably reflected sitespecific controls on net radiation. This was most apparent for Site 1 where the development of a broad-leaved tree canopy in the spring strongly influences energy transfers to 


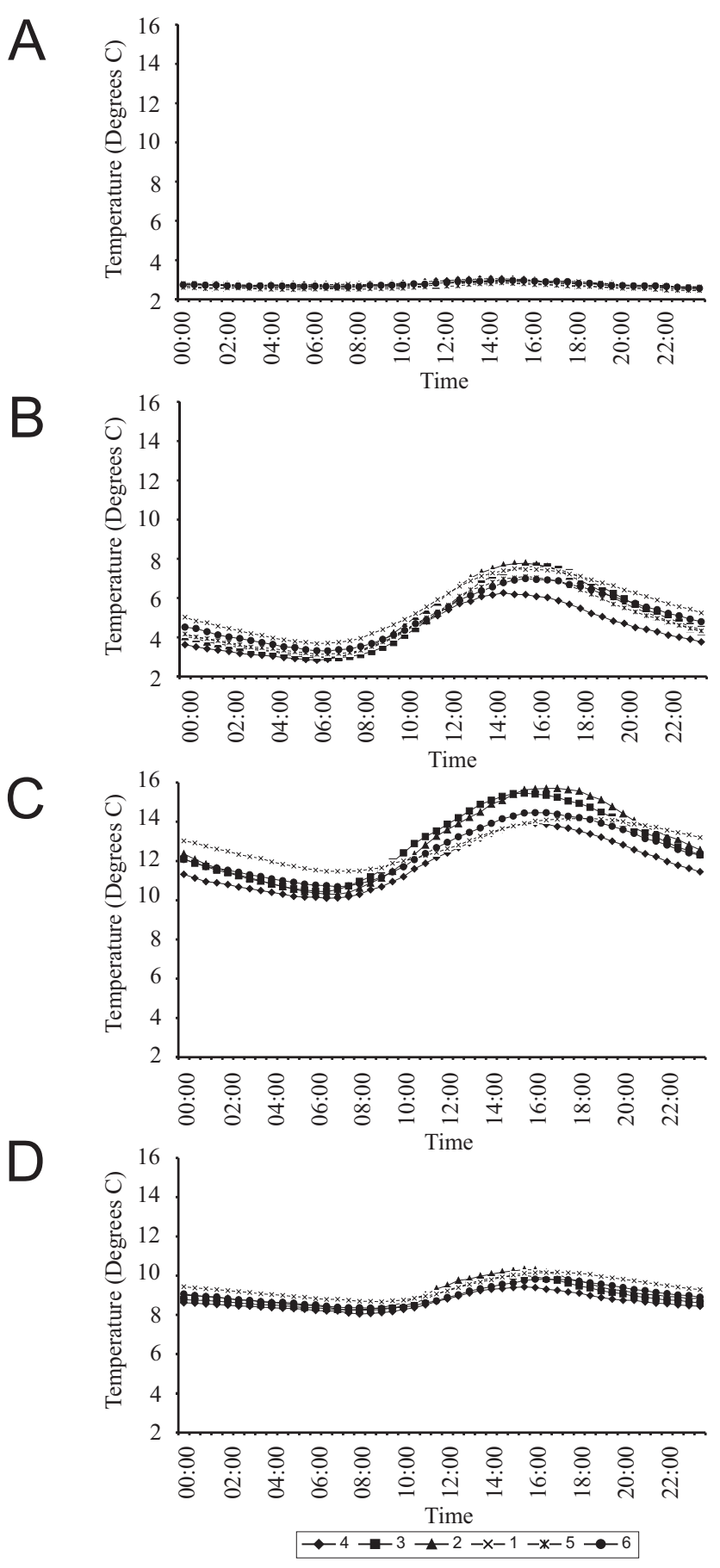

Fig. 7. Mean diel temperture cycle at sites 1-6 for December 2000 (A), April 2001 (B), August 2001 (C) and October 2001 (D).

the stream below. Inter-site variability during winter months was small, inconsistent and within the measurement error of the temperature dataloggers. To provide a framework for further discussion of the findings, Fig. 8 provides a conceptual model of the main controls on spatial temperature variability operating at the catchment and reach-scale, together with a brief description of their influences on stream temperature.

Catchment topography, channel incision, channel orientation (Webb and Zhang, 1997; Arscott et al., 2001; Poole and Berman, 2001) and riparian vegetation (Beschta and Taylor, 1988; Sinokrot and Stefan, 1993; Stott and Marks, 2000; Isaak and Hubert, 2001) all affect stream surface shading. This shading moderates high stream temperatures by reducing incident short-wave radiation. Shading can affect both the timing and magnitude of stream temperature changes. Where riparian vegetation provides channel shading, most notably at Site 1 , short-wave radiation can be reflected or absorbed by the canopy, or transmitted through to the ground/stream (the latter is typically $<20 \%$, but can be as little as $5 \%$ of the incident short-wave flux; Oke, 1987). However, riparian vegetation also emits longwave radiation toward the stream and reduces windiness (and consequently evaporative heat loss) which are likely to be important in reducing the nocturnal net radiative deficit compared with more open sites (Sinokrot and Stefan, 1993). These combined effects can result in substantially moderated thermal regimes in forested areas compared with sites with more open vegetation.

Channel geometry (including width-depth ratios and channel morphology) affects the surface area available for energy exchange between the stream and atmosphere (Hawkins et al., 1997). High width-depth ratios often generate large diel temperature fluctuations, warmer daytime and cooler night-time temperatures than sites with lower width to depth ratios. Channel gradient affects energy inputs from friction at the bed and banks. Steep channel reaches gain energy (heat) from friction especially at higher stream flows (Hannah et al., in press).

The hydrology of catchments also exerts substantial control on thermal regime. Groundwater inflow, which is strongly influenced by geology, together with surface and sub-surface geomorphology (Malcolm et al., 2003) also influences surface water temperatures strongly (Arscott et al., 2001). Groundwater is thermally stable relative to nearsurface and surface water and as such can often moderate temperature extremes where it is a substantial component of runoff (Constantz, 1998; Mellina et al., 2002; Hannah et al., in press). However, these effects may be highly localised depending on equilibration times for surface water. Hyporheic exchange is also known to reduce stream temperatures (Story et al., 2003) and this could play a role in reducing temperatures in the lower Girnock (Site 1) where hyporheic storage is substantial (Malcolm, 2002).

On the basis of the findings of this study it is possible to divide the Girnock Burn into four broadly similar areas according to differences in channel characteristics and 


\section{Catchment Scale controls}
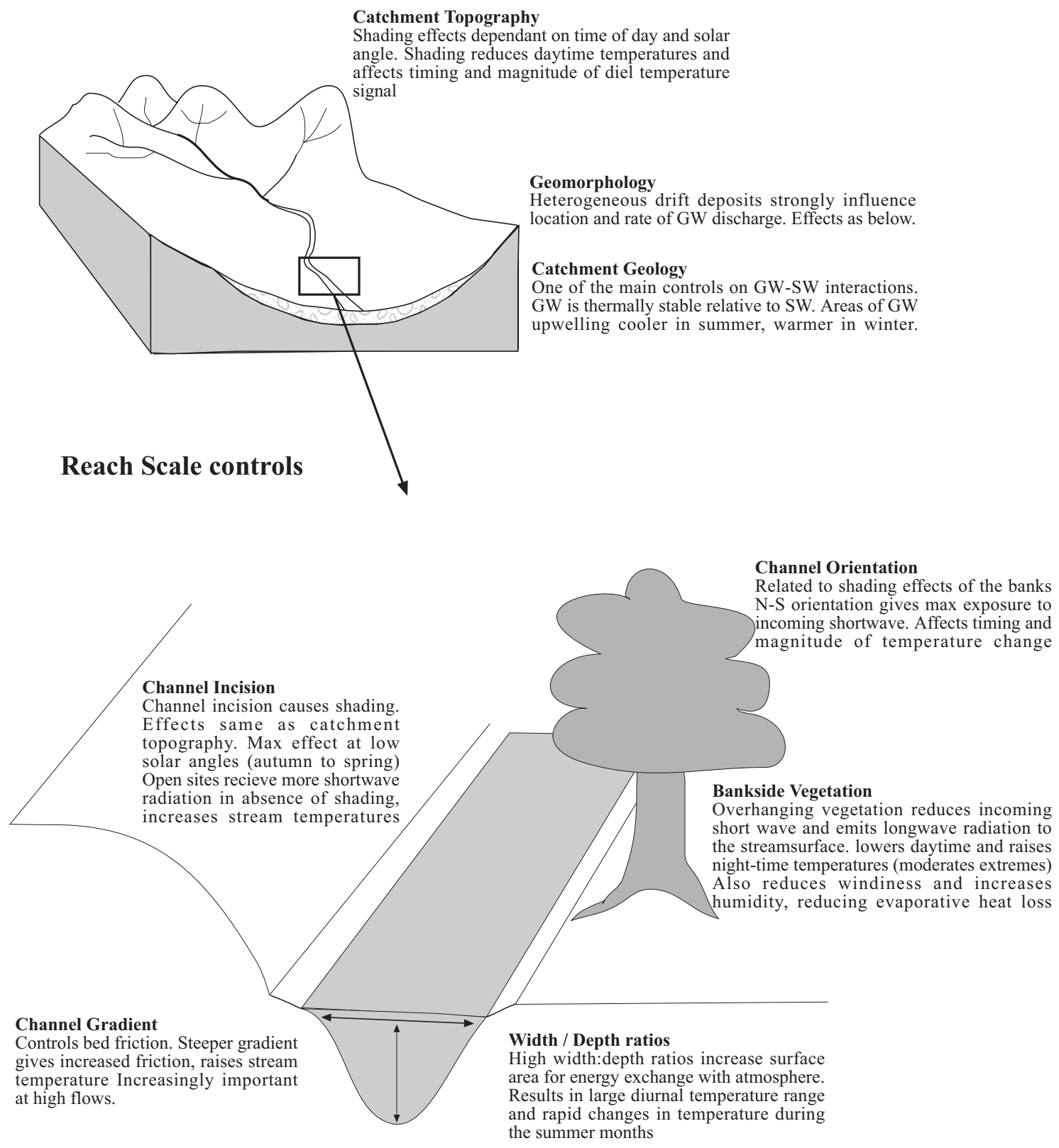

Fig. 8. Conceptual diagram showing the dominant controls on the spation variability of stream temperature

thermal regime. In the upper catchment (Site 4), a combination of altitude, channel incision (shading through topographic effects) and close proximity to groundwater sources (prior to thermal equilibration with surrounding conditions) reduced stream temperatures between spring and autumn. In the middle of the catchment (Sites 2 and 3), open aspect and high width-depth ratios produced high mean temperatures and rapid temperature fluctuations, with extremely low and high temperatures compared with sites elsewhere in the catchment. In the lower catchment (Site
1), riparian woodland appeared to moderate stream temperatures, although the effect was more marked for maxima rather than minima. Consequently, stream temperatures at Site 1 were more comparable with Site 4, rather than Sites 2 and 3. Sites 5 and 6 exhibited characteristics intermediate to Sites $2 / 3$ and Site 4 . They were located at a similar altitude to Sites $2 / 3$, but exhibited far lower width-depth ratios and a higher degree of channel incision.

Changes in thermal regime observed throughout the 
Girnock Burn stream network were non-linear with distance downstream, but are likely to have a substantial implications for stream ecology (Weatherley and Ormerod, 1990). This inter-site variability should be taken into account when considering ecological processes. Physiological and ecological processes in streams are profoundly affected by temperature. In addition to absolute values, spatial and temporal variability of stream temperatures are likely to impact processes occurring at fine scales. In the Girnock Burn, temperature varied cyclically on a daily basis, most markedly at Sites 2 and 3 when short-wave inputs dominated energy accumulation. In early summer, the amplitude of the diel temperature on individual days spanned $>10$ degrees $\left(>5^{\circ} \mathrm{C}\right.$ on average) at sites 2 and $3,50 \%$ of the total annual range. The likely effects of such variation on the behaviour and physiology of stream salmonids have not been emphasised in previous studies, perhaps because such largeamplitude variation is not characteristic of all stream types. However, the Girnock Burn is typical of many upland streams, being shallow and of open aspect and it is likely that diel temperature cycles of similarly extreme amplitude do occur in many other streams.

Typically, summary values for temperature, such as daily means, are used to explain variations in food acquisition, assimilation and storage in salmonids (Jones et al., 2002). While these measures may be effective proxies (Metcalfe and Thorpe, 1990), diel variation is also expected to be an effect on growth since growth varies non-linearly with temperature (Elliott and Hurley, 1997). Furthermore, if efficiency of food acquisition and digestive efficiency differ in their dependency on temperature, diel patterns of feeding and assimilation are expected to optimise differently at different times of year. This may condition behavioural strategies. If it does, spatial variation in diel temperature regimes may lead to reach-scale variations in feeding strategy. Potentially, all of these effects impinge on the growth and performance of individual and populations of salmonids and other aquatic species.

The significant influence of riparian woodland on the thermal regime of the lower Girnock Burn, and its concomitant implications for the functional ecology of this important salmon stream has much wider implications regarding the impacts of forest management on freshwater ecosystems. Whilst some studies have examined the influence of traditional UK conifer plantations on stream temperatures (Weatherley and Ormerod, 1990), the effects of native mixed and broadleaved woodland are much less well-understood (Brogan and Soulsby, 1996). Current forest policy favours the re-establishment of native riparian woodlands, often on aesthetic grounds, but also on the basis of assumed ecological benefits, particularly in salmon streams (e.g. the Tweed Foundation Rankle Burn Scheme). It appears that moderation of high summer water temperatures is likely to be beneficial to salmonids, given that predictions of higher summer water temperatures resulting from current climatic change scenarios in the Scottish Highlands may result in increased thermal stress and potentially lethal effects (Langan et al., 2001). However, the influence of riparian woodlands on stream energy budgets has much broader implications for the entire functional ecology of stream ecosystems, with effects on primary and secondary production, and subsequent impacts on salmon populations are difficult to predict. Thus, there is a clear need for focussed process studies which will allow the effects of current riparian forestry policy on freshwater habitats to be more fully understood.

\section{References}

Arscott, D.B., Tockner, K. and Ward, J.V., 2001. Thermal heterogeneity along a braided floodplain river (Tagliamento River, northeastern Italy) Can. J. Fish. Aquat. Sci., 58, 23592373.

Beschta, R.L., and Taylor, R.L., 1988. Stream temperature increases and land use in a forested Oregon watershed. Water Resour. Bull. 24, 19-25.

Boon, P.J.,1987. The influence of Kielder water on Trichopteran (Caddisfly) populations in the River North Tyne (northern England). Regul. River. 1, 95-109.

Boon, P.J., 1993. Distribution, abundance and development of Trichoptera larvae in the River North Tyne following commencement of hydroelectric power generation. Regul. River. 8, 211-224.

Brogan, J. and Soulsby, C., 1996. Managing riparian tree cover in the Scottish highlands, a case study of Glen Tannar. Scottish Forestry, 50, 133-144.

Constantz, J., 1998. Interaction between stream temperature, streamflow, and groundwater exchanges in alpine streams. Water Resour. Res. 34, 1609-1615.

Crisp, D.T., 1996. Environmental requirements of common riverine European salmonid fish species in fresh water with particular reference to physical and chemical aspects. Hydrobiologia, 323, 201-221.

Elliott J.M. and Hurley, M.A., 1997. A functional model for the maximum growth of Atlantic salmon parr, Salmo salar, from two populations in north west England. Funct. Ecol., 11, 592603.

Elliot, J.M. and Hurley, M.A., 1998. An individual-based model for predicting the emergence period of sea trout fry in a lake district stream. J. Fish Biol., 53, 414-433.

Evans, E.C., McGregor, G.R. and Petts, G.E.,1998. River energy budgets with special reference to river bed processes. Hydrol. Process., 12, 575-595.

$\mathrm{Gu}$, R.R. and Li, Y., 2002. River temperature sensitivity to hydraulic and meteorological parameters. J. Environ. Manage., 66, 43-56.

Hannah, D., Malcolm, I.A., Soulsby, C. and Youngson, A.F., In press. Heat Exchanges and Temperature Behaviour within a Salmon Spawning Stream in the Cairngorms, Scotland. River Res. Appl. 
Hawkins, C.P., Hogue, J.N. Decker, L.M., Feminella, J.W., 1997. Channel morphology, water temperature, and assemblage structure of stream insects. J. N. Amer. Benthol. Soc., 16, 728749.

Isaak, D.J., and Hubert, W.A., 2001. A hypothesis about the factors that affect maximum summer stream temperatures across montane landscapes. J. Amer. Water Resour. Ass., 37, 351-366.

Jones, W., Gurney, W.C., Speirs, D.C., Bacon, P.J. and Youngson, A.F., 2002. Seasonal patterns of growth, expenditure and assimilation in juvenile Atlantic salmon. J. Anim. Ecol., 71, 916924.

Langan, S.J., Johnston, L., Donaghy, M.J., Youngson, A.F., Hay, D.W. and Soulsby, C., 2001. Variation in river water temperatures in an upland stream over a 30 -year period. Sci. Total Envir., 265, 195-207.

Malard, F., Mangin, A., Uehlinger, U. and Ward, J.V., 2001. Thermal heterogeneity in the hyporheic zone of a glacial floodplain. Can. J. Fish. Aquat. Sci., 58, 1319-1335.

Malcolm, I.A., 2002. Groundwater-surface water interactions in the hyporheic zone of salmon spawning streams: hydrology, hydrochemistry and ecological response. Unpublished $\mathrm{PhD}$ thesis, University of Aberdeen, UK.

Malcolm, I.A., Soulsby, C., Youngson and A., Petry J., 2003. Heterogeneity in ground water - surface water interactions in the hyporheic zone of a salmonid spawning stream Hydrol. Process., 17, 601-617.

Mellina E., Moore, R.D., Hinch, S.G., Macdonald, J.S. and Pearson, G., 2002. Stream temperature responses to clearcut logging in British Columbia: the moderating influences of groundwater and headwater lakes. Can. J. Fish. Aquat. Sci., 59, 1886-1900.

Metcalfe, N.B. and Thorpe, J.E., 1990. Determinants of geographical variation in the age of seaward-migrating salmon, Salmo salar. J. Anim. Ecol., 59, 135-145.

Mohensi, O. and Stefan, H.G., 1999. Stream temperature/air temperature relationship: a physical interpretation. J. Hydrol., 218, 128-141.

Moir, H.J., 1999. Characterisation of salmon spawning habitat in the Dee catchment, NE Scotland. Unpublished PhD thesis, University of Aberdeen, UK.
Poole, G.C. and Berman, C.H., 2001. An ecological perspective on in-stream temperature: Natural heat dynamics and mechanisms of human-caused thermal degradation. Environ. Manage., 6, 787-802.

Sinokrot, B.A. and Stefan, H.G., 1993. Stream temperature dynamics: measurements and modeling. Water Resour. Res., 29, 2299-2312.

Story, A., Moore, R.D. and Macdonald, J.S., 2003. Stream temperatures in two shaded reaches below cutblocks and logging roads: downstream cooling linked to subsurface hydrology. Can. J. For. Res., 33, 1383-1396.

Stott, T. and Marks, S., 2000. Effects of plantation forest clearfelling on stream temperatures in the Plynlimon experimental catchments, mid-Wales. Hydrol. Earth Syst. Sci., 4, 95-104.

Soulsby, C. and Boon, P., 2001. Freshwater Environments in Scotland: an Earth Science perspective on the natural heritage of Scotlands rivers. In: Earth Science and the Natural Heritage., J. Gordon and K. Leys (Eds.) Stationary Office, London, UK. $82-104$.

Townsend, C.R., Hildrew, A.G., and Francis, J., 1983. Community structure in some southern English streams: the influence of physicochemical factors. Freshwater Biol., 13, 521-544.

Warren, J.S., 1985. Hydrology of the River Dee and its tributaries. In: The biology and management of the River Dee, D. Jenkins, (Ed.). ITE Symposium Series No. 14. Huntingdon: Institute of Terrestrial Ecology, UK. 23-28.

Weatherley, N.S. and Ormerod, S.J., 1990. Forests and the temperature of upland streams in Wales: a modelling exploration of the biological effects. Freshwater Biol., 24, 109-122.

Webb, B.W. and Nobilis, F., 1997. Long-term perspective on the nature of the air-water temperature relationship: a case study. Hydrol. Process., 11, 137-147.

Webb, B.W. and Zhang, Y., 1997. Spatial and seasonal variability in the components of the river heat budget. Hydrol. Process., 11, 79-101.

Youngson, A.F., Malcolm, I.A., Thorley, P.J., Bacon, P.J. and Soulsby, C., In press. Long residence groundwater effects on incubating salmonid eggs: low hyporheic oxygen impairs embryo development. Can. J. Fish. Aquat. Sci. 